\title{
IMAGEN DE LA MEDICINA
}

\section{Heinrich Hermann Robert Koch ${ }^{*}$}

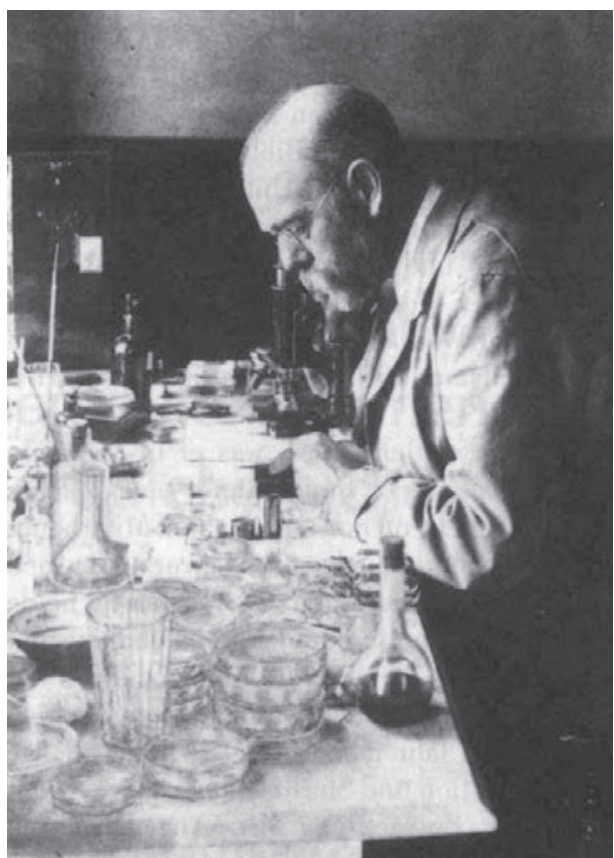

Nació en Clausthal, Reino de Hannover, el 11 de diciembre de 1843, y murió en Baden-Baden, Gran Ducado de Baden, imperio alemán, el 27 de mayo de 1910.

Heinrich Hermann Robert Koch tiene un sitio de honor en la historia de la medicina, por descubrir el bacilo de la tuberculosis, en 1882. Sus hallazgos los presentó el 24 de marzo de 1882.
Descubrió, además, el bacilo del cólera, en 1883, y desarrolló los postulados de Koch. Recibió el Premio Nobel de Medicina en 1905 y es considerado el fundador de la bacteriología.

* Este texto lo editó Luis Fernando Jaramillo G., a partir de lo encontrado en http://www.wikipedia.org. 
El trabajo de Koch consistió en aislar el microrganismo causante de esta enfermedad y hacerlo crecer en un cultivo puro, que utilizó para inducir la enfermedad en animales de laboratorio - en su caso, la cobaya-, aislando de nuevo el germen de los animales enfermos para verificar su identidad y com- parándolo con el germen original.

Probablemente tan importante como su trabajo en la tuberculosis sean los llamados postulados de Koch, que establecen las condiciones para que un organismo sea considerado la causa de una enfermedad.

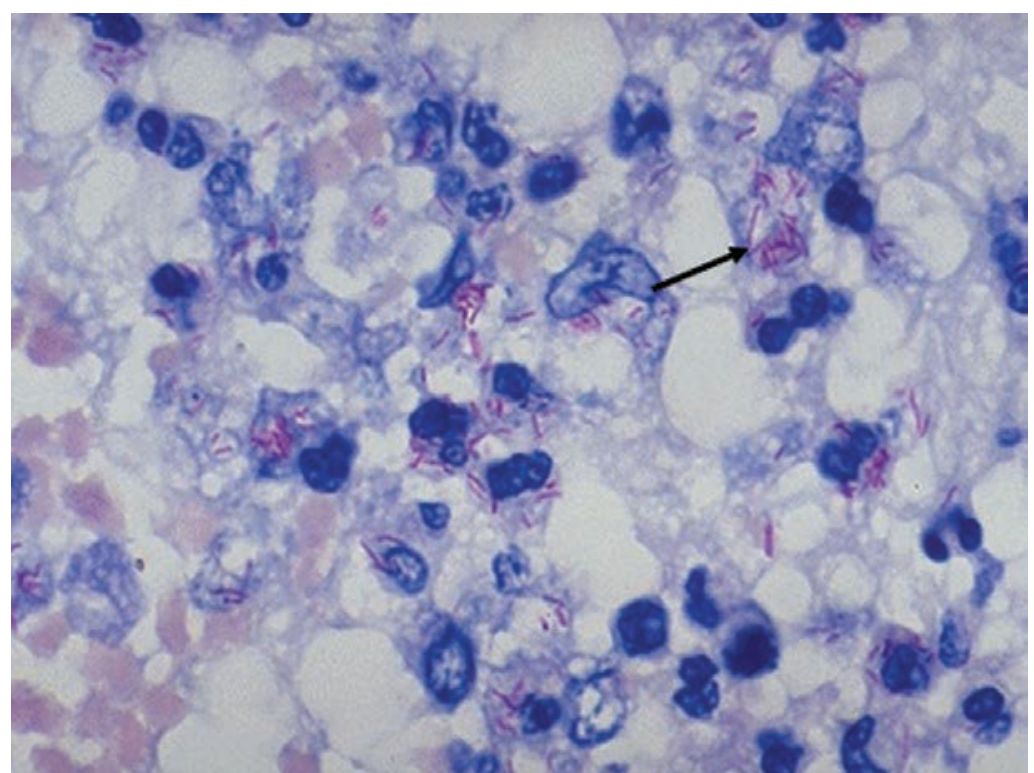

Micobacterias en esputo (coloración de ZN 100x)

Fuente: colección del Departamento de Patología de la Pontificia Universidad Javeriana-Hospital Universitario San Ignacio. 